\title{
PELAKSANAAN PEMBELAJARAN BAHASA INDONESIA KURIKULUM 2013 DI KELAS XI SMA NEGERI 2 KOTA BENGKULU
}

\author{
Michael Johan Sulistiawan ${ }^{1}$, Didi Yulistio ${ }^{2}$, dan M. Arifin ${ }^{3}$ \\ ${ }^{1,2,3}$ Program Studi Pendidikan Bahasa dan Sastra Indonesia \\ Jurusan Pendidikan Bahasa dan Seni \\ FKIP Universitas Bengkulu \\ michael johan@yahoo.com
}

\begin{abstract}
Abstrak
Tujuan penelitian ini adalah untuk mendeskripsikan pelaksanaan pembelajaran bahasa Indonesia di kelas XI SMA Negeri 2 Kota Bengkulu. Penelitian ini menggunakan pendekatan kualitatif dengan metode deskriptif. Teknik yang digunakan dalam mengumpulkan data adalah observasi dan wawancara. Analisis data dilakukan dengan cara; 1) mengelompokkan data; 2) menyajikan data; dan 3) menarik kesimpulan. Hasil penelitian menunjukkan bahwa guru bahasa Indonesia kelas XI SMA Negeri 2 Kota Bengkulu melaksanakan pembelajaran bahasa Indonesia dengan langkah-langkah seperti yang ada dalam Kurikulum 2013 yaitu; 1) kegiatan pendahuluan, 2) kegiatan inti, dan 3) kegiatan penutup. Beberapa saran yang hendak penulis sampaikan yakni: 1) guru hendaknya meningkatkan pemahaman mengenai Kurikulum 2013 dengan mengikuti seminar, workshop, pelatihan mengenai Kurikulum 2013 atau mempelajari buku-buku Kurikulum 2013; 2) pihak Sekolah hendaknya secara berkala mengadakan pelatihan atau seminar Kurikulum 2013; 3) bagi peneliti, perlunya dilakukan penelitian lanjutan berkenaan dengan pelaksanaan pembelajaran untuk sekolah-sekolah yang menggunakan Kurikulum 2013.
\end{abstract}

\section{Kata kunci: Pelaksanaan, Pembelajaran, Bahasa Indonesia, Kurikulum 2013}

\begin{abstract}
The purpose of this study is to describe the implementation of Indonesian language learning in the class XI SMA Negeri 2 Kota Bengkulu. This research uses qualitative approach with descriptive method. Techniques used in collecting data are observation, document recording, and interview. The results showed that Indonesian teachers of class XI SMA Negeri 2 Kota Bengkulu carry out Indonesian language learning with the steps as in the Curriculum 2013, namely; 1 ) preliminary activities, 2) core activities, and 3) closing activities. Some suggestions the author wishes to convey are: 1) the teacher should improve the understanding of the Curriculum 2013 by attending seminars, workshops, training on Curriculum 2013 or studying books Curriculum 2013; 2) School parties should regularly conduct training or seminars of Curriculum 2013; 3) for the researcher, there is a need for further research regarding the implementation of learning for schools using the Curriculum 2013.
\end{abstract}

Keywords: Implementation, Learning, Indonesia Language, Curriculum 2013 


\section{PENDAHULUAN}

Indonesia pada saat ini tengah berupaya menciptakan pendidikan yang berkualitas untuk memenuhi tuntutan kebutuhan masyrakat. Berbagai upaya dilakukan, diantaranya yaitu dengan melakukan perubahan kurikulum. Kurikulum di Indonesia sendiri telah mengalami beberapa kali perubahan sampai pada saat ini kurikulum terbaru yakni Kurikulum 2013. Kurikulum sendiri juga dinilai memegang peranan sangat penting dalam dunia pendidikan, berhasil atau tidaknya tujuan pendidikan juga turut ditentukan oleh kurikulum yang digunakan. Seperti yang dikemukakan oleh Fadlilah (2014:13-14), kurikulum merupakan sebuah wadah yang akan menentukan arah pendidikan.

Pembelajaran dalam konteks Kurikulum 2013 diorientasikan untuk menghasilkan insan Indonesia yang produktif, kreatif, inovatif, dan afektif melalui pengetahuan sikap (tahu mengapa), keterampilan (tahu bagaimana), dan pengetahuan (tahu apa) yang terintegrasi (Abidin, 2014: 14).

Fadlillah (2014:175) menyebutkan bahwa dalam pembelajaran Kurikulum 2013, terdapat karakteristik yang menjadi ciri khas pembeda dengan kurikulumkurikulum yang telah ada selama di Indonesia. Karakteristik Kurikulum 2013 adalah pendekatan pembelajaran yang mengusung pendekatan scientific dan tematik-integratif, kompetensi lulusan yang mencakup aspek sikap, pengetahuan, dan keterampilan, serta evaluasi yang menggunakan penilaian otentik.

Dalam Permendukbud No 22 Tahun 2016 disebutkan bahwa komponenkomponen Kurikulum 2013 diantaranya yakni meliputi perencanaan pembelajaran, pelaksanaan pembelajaran, dan evaluasi pembelajaran.

Dalam Permendikbud Nomor 22 Tahun 2016 menyebutkan bahwa Rencana
Pelaksanaan Pembelajaran (RPP) adalah rencana kegiatan pembelajaran tatap muka untuk satu pertemuan atau lebih. RPP dikembangkan dari silabus untuk mengarahkan kegiatan pembelajaran peserta didik dalam upaya mencapai Kompetensi Dasar (KD). Istilah standar kompetensi tidak lagi dikenal pada kurikulum 2013, namun muncul istilah baru yaitu Kompetensi Inti.

Dalam Permendibud Nomor 22 Tahun 2016 dijelaskan bahwa pelaksanaan pembelajaran merupakan implementasi dari RPP, meliputi kegiatan pendahuluan, inti dan penutup. Pada kegiatan pendahuluan, guru wajib: 1) menyiapkan peserta didik secara psikis dan fisik untuk mengikuti proses pembelajaran; 2) memberi motivasi belajar peserta didik; 3) mengajukan pertanyaan-pertanyaan yang mengaitkan pengetahuan sebelumnya; 4) menjelaskan tujuan pembelajaran atau kompetensi dasar yang akan dicapai; dan 5) menyampaikan cakupan materi dan penjelasan uraian kegiatan sesuai silabus.

Pada kegiatan inti menggunakan model, metode, media, dan sumber belajar yang disesuaikan dengan karakteristik peserta didik dan mata pelajaran. Pemilihan pendekatan tematik dan /atau tematik terpadu dan/atau saintifik dan/atau inkuiri dan penyingkapan (discovery) dan/atau pembelajaran yang menghasilkan karya berbasis pemecahan masalah (project based learning) disesuaikan dengan karakteristik kompetensi dan jenjang pendidikan.

Pada kegiatan penutup, guru bersama peserta didik baik secara individual maupun kelompok melakukan refleksi untuk mengevaluasi: 1) seluruh rangkaian aktivitas pembelajaran dan hasil-hasil yang diperoleh; 2) memberikan umpan balik terhadap proses dan hasil pembelajaran; 3) melakukan kegiatan tindak lanjut; 4) menginformasikan rencana kegiatan 
pembelajaran untuk pertemuan berikutnya.

Dalam Permendikbud Nomor 22 Tahun 2016 menyebutkan bahwa penilaian proses pembelajaran dengan menggunakan pendekatan penilaian otentik (authentic assesment) adalah menilai kesiapan peserta didik, proses, dan hasil belajar secara utuh. Keterpaduan penilaian ketiga komponen tersebut akan menggambarkan kapasitas, gaya, dan perolehan belajar peserta didik yang mampu menghasilkan dampak instruksional (instructional effect) pada aspek pengetahuan dan dampak pengiring (nurturant effect) pada aspek sikap.

Pendekatan yang digunakan dalam pembelajaran Kurikulum 2013 ialah scientific dan tematik-integratif. Menurut Fadlillah (2014: 176), Pendekatan Saintifik adalah pendekatan pembelajaran yang dilakukan melalui proses mengamati (observing), menanya (questioning), mencoba (experimenting), menalar (associating), dan mengkomunikasikan (communication). Model pembelajaran proses saintifik merupakan model pembelajaran yang menuntut siswa beraktivitas sebagaimana seorang ahli sains. Dalam praktiknya siswa diharuskan beraktivitas selayaknya langkah-langkah penerapan metode ilmiah (Abidin, 2014:122).

Peran guru dalam keberhasilan pelaksanaan Kurikulum 2013 tentu sangatlah besar. Guru tentunya dituntut untuk lebih kreatif dari yang sebelumnya agar dapat menciptakan pembelajaran yang menarik bagi peserta didik, terlebih aspek sikap spiritual dan sikap sosial belum pernah ada dalam kurikulum-kurikulum sebelumnya. Seperti yang disampaikan oleh Sukmadinata, (2010:191) bahwa pendidikan berintikan interaksi antara pendidik (guru) dan peserta didik (siswa) untuk mencapai tujuan-tujuan pendidikan. Pendidik, peserta didik, dan tujuan pendidikan merupakan komponen utama pendidikan. Ketiganya membentuk suatu triangle, jika hilang salah satu komponen, hilang pulalah hakikat pendidikan.

Guru tetap sebagai fasilitator dan motivator, namun dia juga memosisikan diri sebagai insan pembelajar. Dalam konteks sumber belajar yang kini makin luas tidak hanya guru dan buku pembelajaran ini sangat sesuai dengan perkembangan teknologi informasi dan komunikasi yaitu internet (Mulyoto, 2013: 12).

Dalam menghadapi perubahan yang ada, kesiapan guru sangatlah perlu untuk diperhatikan. Seperti yang disampaikan oleh Muzamiroh (2013: 121) apabila guru memiliki kesiapan yang memadai, siap dalam segi kualisi dan kompetensi serta siap dalam hal kesamaan pemahaman paradigma pendidikan yang dijabarkan di dalam kurikulum. Hal serupa juga disebutkan oleh Husamah dan Yanur (2013:14-15) bahwa keberhasilan Kurikulum 2013 nanti tidak bisa terlepas dari peran guru sebagai ujung tombak pendidikan. Namun, kesiapan guru menghadapi tantangan kurikulum baru ini perlu menjadi perhatian.

Sebagai kurikulum yang baru, Kurikulum 2013 akan menghadapi berbagai masalah dan tantangan dalam pelaksanaannya. Seperti yang dikemukakan oleh Kurinasih \& Berlin (2014: 6-7) tentang perubahan Kurikulum 2013 yang terjadi saat ini, ia berpendapat bahwa dari sekian banyak perubahan yang terjadi tentu saja ada "cacat" dalam pengimplementasian perubahan kurikulum, hal ini bisa saja karena kurangnya keterampilan, pengetahuan, serta kemampuan guru dalam memahami tugas-tugas yang harus ia emban dan laksanakan.

SMA Negeri 2 Kota Bengkulu merupakan salah satu sekolah menengah atas yang pertama kali menerapkan Kurikulum 2013 di Kota Bengkulu. Sebagai 
sekolah menengah atas yang pertama kali menggunakan Kurikulum 2013 tentunya sudah banyak proses yang telah ditempuh dalam pembelajaran di kelas juga pelatihan bagi guru di SMA Negeri 2 Kota Bengkulu. Tujuan penelitian ini adalah untuk mendeskripsikan pelaksanaan pembelajaran bahasa Indonesia di kelas XI Sekolah Menengah Atas Negeri 2 Kota Bengkulu.

\section{METODE}

Penelitian ini menggunakan pendekatan kualitatif dengan metode deskriptif.

Data dalam penelitian ini yakni pembelajaran bahasa Indonesia di kelas XI MIPA A dan XI MIPA B Sekolah Menengah Atas Negeri 2 Kota Bengkulu. Sumber data dalam penelitian ini yakni Yunial Fahmi, M.Pd. selaku guru bahasa Indonesia di kelas XI MIPA A dan XI MIPA B, serta peserta didik yang berjumlah 69 siswa dari kelas XI MIPA A dan XI MIPA B.

Teknik pengumpulan data pada penelitian ini observasi dan wawancara.

\section{HASIL DAN PEMBAHASAN}

Pada pelaksanaan pembelajaran bahasa Indonesia di kelas, guru melaksanakan pembelajaran seperti yang ada dalam Kurikulum 2013. Guru dalam pelaksanaan pembelajaran bahasa Indonesia menggunakan Kompetensi Inti satu, dua, tiga, dan empat dalam Kurikulum 2013 sebelum direvisi. Guru menggunakan Kompetensi Inti dan Kompetensi Dasar Kurikulum 2013 sebelum direvisi karena silabus yang diterima oleh guru memuat Kompetensi Inti dan Kompetensi Dasar sebelum direvisi.

Indikator pembelajaran yang digunakan guru merupakan hasil turunan dari Kompetensi Dasar yang digunakan oleh guru. Dalam pelaksanaan pembelajaran bahasa Indonesia di kelas, guru melaksanakan pembelajaran sesuai dengan RPP yang dibuat oleh guru.

Pada pelaksanaan pembelajaran bahasa Indonesia di kelas XI guru telah mencapai tujuan pembelajaran yang sebelumnya telah dirumuskan oleh guru dalam RPP.

Materi pembelajaran yang digunakan guru yakni drama dan film. Guru tidak "Guyonan bersama Pementasan Teater Gandrik Gundala Gawat" Dwi Klik Santosa dan Teks ulasan drama karya siswa. Namun, dalam pelaksanaannya guru menggunakan teks drama yang dibawa peserta didik dari rumah. Pada pelaksanaan pembelajaran terkadang tidak semua dapat diterapkan dalam pembelajaran. Beberapa yang ada dalam RPP digunakan sebagai acuan dalam pelaksanaan, namun terkadang dalam pelaksanaan pembelajaran juga menemui kendala-kendalanya.

Pendekatan pembelajaran yang digunakan guru pada pelaksanaan pembelajaran bahasa Indonesia di kelas yakni pendekatan saintifik dengan tahap mengamati, menanya, menalar, dan mengkomunikasikan. Kendala yang dihadapi oleh guru dalam menerapkan pendekatan saintifik yakni pada tahap mencoba karena tidak semua dalam mata pelajaran bahasa Indonesia dapat dilakukan dengan cara eksperimen. Guru juga menggunakan pendekatan berbasis teks dalam kegiatan pembelajaran di kelas, namun hanya pada tahap pemodelan. Guru belum menerapkan tahap membangun teks secara kelompok dan mandiri.

Model pembelajaran yang digunakan guru pada pelaksanaan pembelajaran bahasa Indonesia di kelas yakni model pembelajaran discovery based learning. Model pembelajaran discovery based learning dipilih guru karena model pembelajaran ini berpusat kepada peserta didik dan guru juga sama-sama 
berperan aktif mengeluarkan pendapatnya, mendorong peserta untuk turut aktif dalam kegiatan pembelajaran, dan di sisi lain peserta didik juga dapat memanfaatkan berbagai jenis sumber belajar.

Metode pembelajaran yang digunakan guru pada pelaksanaan pembelajaran bahasa Indoensia di kelas yakni metode diskusi dan Tanya jawab. Metode diskusi dan tanya jawab digunakan guru karena melihat materi pembelajaran yang digunakan guru. Diskusi dan tanya jawab dirasa tepat dalam hal ini, karena dengan diskusi dan tanya jawab peserta didik dapat bertukar pendapat baik sesama peserta didik maupun peserta didik dengan guru, peserta didik juga dapat turut aktif dalam kegiatan pembelajaran bukan hanya sekedar menerima materi pembelajaran.

Media pembelajaran yang digunakan guru pada pelaksanaan pembelajaran bahasa Indonesia di kelas dan alat pembelajaran yang digunakan yakni LCD dan laptop. Media power point dipilih guru karena guru ketika di rumah dapat mempersiapkan materi dan ketika guru berada di kelas, guru hanya tinggal menampilkan dan memberi penjelasan kepada peserta didik. Media ini digunakan karena lebih efektif dan efesien. Untuk membantu guru dalam menjelaskan materi, guru juga menggunakan papan tulis.

Sumber belajar yang digunakan guru yakni buku Bahasa Indonesia Ekspresi diri dan Akademik. Buku tersebut merupakan buku dari pemerintah yang disediakan bagi setiap sekolah yang menggunakan Kurikulum 2013. Kendalanya yakni setiap peserta didik hanya diberi satu buku untuk dua peserta didik. Hal tersebut dikarenakan jumlah buku yang terbatas. Teks prosedur kompleks digunakan guru untuk pedoman bagi peserta didik ketika nantinya mereka membuat film. Materi tentang teks prosedur kompleks sendiri telah diajarkan kepada peserta didik pada pertemuan-pertemuan sebelumnya.

Pada pelaksanaan pembelajaran di kelas guru menggunakan langkah-langkah dalam Kurikulum 2013 di antaranya kegiatan pendahuluan, inti dan penutup. Pada kegiatan inti, guru menggunakan pendekatan saintifik dengan tahap kegiatan mengamati, bertanya, menalar, dan mengkomunikasikan. Hal tersebut belum sepenuhnya sesuai dengan Lampiran Permendikbud 103 Tahun 2014 tentang Pembelajaran pada Pendidikan Dasar dan Pendidikan Menengah karena guru belum menerapkan langkah mencoba.

Kendala yang dihadapi guru dalam pelaksanan pembelajaran bahsa Indonesia di kelas di antaranya yakni peserta didik tidak konsen ketika mereka mengikuti pembelajarann di kelas, peserta didik banyak kegiatan di luar kelas yang membuat mereka nantinya akan ketinggalan materi pembelajaran karena ketika guru menjelaskan materi mereka tidak berada di kelas, peserta didik terkadang terlambat dalam mengumpulkan tugas bahkan terkadang mereka tidak mengumpulkan, buku yang disediakan pemerintah tidak mencukupi sehingga dua peserta didik harus menggunakan satu buku.

Pada pelaksanaan pembelajaran bahasa Indonesia di kelas XI MIPA A guru menggunakan penilaian autentik dengan jenis pengetahuan tes tertulis. Sedangkan Pada pelaksanaan pembelajaran bahasa Indonesia di kelas XI MIPA B guru menggunakan penilaian autentik dengan jenis pengetahuan tes lisan. Untuk penilaian sikap, guru bekerja sama dengan guru mata pelajaran agama dan PKN. Beberapa hal juga dapat dilakukan oleh guru seperti penilaian tanggung jawab yang dapat dilihat dari jumlah 
tugas yang diselesaikan oleh peserta didik setiap kali guru memberi tugas.

Penilaian autentik dinilai lebih tepat oleh guru dalam melaksanakan penilaian karena penilaian autentik lebih lengkap dan dengan hal seperti itu guru dapat mempertanggung jawabkan kinerjanya. Kendalanya adalah guru perlu benarbenar memperhatikan peserta didik satu per satu sedangkan jumlah peserta didik yang ada cukuplah banyak. Di kelas XI MIPA A jumlah peserta didik yakni 34 orang dan di kelas XI MIPA B yakni 35 orang.

\section{PENUTUP}

\section{Kesimpulan}

Dari hasil dan pembahasan di atas, maka dapat disimpulkan bahwa guru bahasa Indonesia kelas XI SMA Negeri 2 Kota Bengkulu melaksanakan pembelajaran bahasa Indonesia dengan menggunakan Kurikulum 2013. Ada pun pendekatan yang digunakan guru di kelas yaitu pendekatan saintifik dengan tahapan kegiatan mengamati, menanya, menalar, dan mengkomunikasikan. Pada kegiatan penilaian, guru menggunakan penilaian autentik yaitu berupa penilaian pengetahuan tes lisan dan tulisan.

\section{Saran}

Berdasarkan hasil penelitian, maka dapat dikemukakan beberapa saran yang hendak penulis sampaikan kepada pihakpihak sebagai berikut.

1) Guru hendaknya meningkatkan pemahaman mengenai Kurikulum 2013 dengan mengikuti seminar, workshop, pelatihan mengenai Kurikulum 2013 atau mempelajari buku-buku Kurikulum 2013.

2) Pihak Sekolah hendaknya secara berkala mengadakan pelatihan atau seminar Kurikulum 2013.
3) Bagi peneliti, perlunya dilakukan penelitian lanjutan berkenaan dengan pelaksanaan pembelajaran untuk sekolah-sekolah yang menggunakan Kurikulum 2013.

\section{DAFTAR PUSTAKA}

Abidin, Yunus. 2014. Desain Sistem Pembelajaran. Bandung: PT Refika Aditama.

Fadlilah. 2014. Implementasi Kurikulum 2013 dalam Pembelajaran SD/MI, SMP/MTS, dan SMA/MA. Yogyakarta: Ar-Ruzz Media.

Husamah \& Yanur Satyaningrum. 2013. Desain Pembelajaran Berbasis Kompetensi: Panduan Merancang Pembelajaran untuk Mendukung Implementasi Kurikulum 2013. Jakarta: Prestasi Pustakarya.

Kurinasih, Imas \& Berlin Sani. 2014. Implementasi Kurikulum 2013: Konsep \& Penerapan. Surabaya: Kata Pena.

Mulyoto. 2013. Strategi Pembelajaran di Era Kurikulum 2013. Jakarta: Prestasi Pustakarya.

Muzamiro, Mida Latifatul. 2013. Kupas Tuntas Kurikulum 2013; Kelebihan dan Kekurangan Kurikulum 2013. Surabaya: Kata Pena.

Permendikbud Nomor 22 Tahun 2016 tentang Standar Proses Pendidikan Dasar dan Menengah.

Sukmadinata, Nana Syaodih. 2010. Pengembangan Kurikulum. Bandung: PT. Remaja Rosdakarya Offset. 